\title{
Isolated midline upper lip pit
}

\author{
Stephanie Hili, ${ }^{1}$ Kai Yuen Wong, ${ }^{1}$ Tim Goodacre ${ }^{2}$
}

${ }^{1}$ Plastic Surgery Department, Salisbury NHS Foundation Trust, Salisbury, UK

${ }^{2}$ The Spires Cleft Centre, Salisbury NHS Foundation Trust, Salisbury, UK

\section{Correspondence to}

Kai Yuen Wong,

kaiyuen.wong@cantab.net

Accepted 30 March 2016

\section{DESCRIPTION}

A fit and well 7-year-old girl presented with an asymptomatic isolated midline upper lip pit (figure 1). This was not associated with cleft lip or palate. Examination revealed no other congenital abnormalities. There was no significant family history. The pit was treated successfully with excision. Intraoperatively, a fistula probe was inserted via the cutaneous opening of the pit, which confirmed no intraoral communication. The entire sinus tract was then excised and the wound directly closed. Histology revealed irregular pilosebaceous units with some fibrous scarring in the upper dermis.

Congenital pits are some of the most uncommon developmental malformations of the lip. Lower lip pits are commonly associated with cleft lip and/or palate in Van der Woude syndrome. The latter can present with a range of other anomalies such as hypodontia, syndactyly and congenital heart defects. ${ }^{1}$ Upper lip pits tend to be non-syndromic epigenetic malformations. Associations with other midline deformities, including double frenulum, sinus of the frenulum, nasal dermoid cyst and

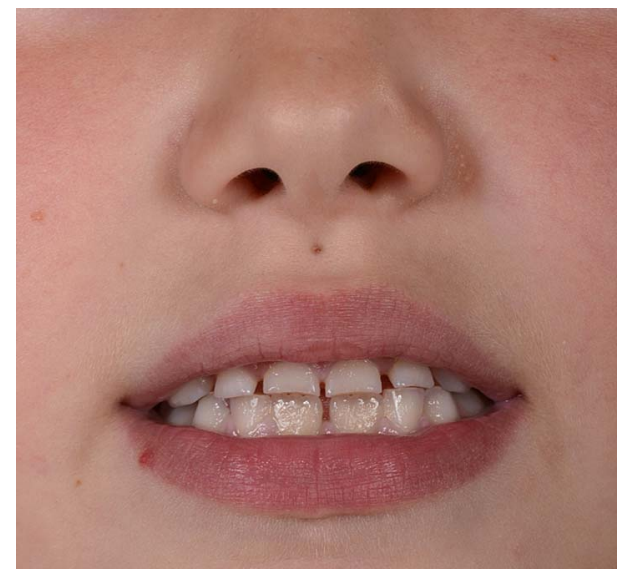

Figure 1 Isolated midline upper lip pit. hypertelorism have also been described. Conversely, only around 18 cases of isolated upper lip pits have been reported.

The mechanisms involved in congenital upper lip sinus formation are incompletely understood. Three main proposals have been suggested including invagination theory, merging theory and fusion theory.

Lip pits can present as asymptomatic irregularities of the lip or with recurrent discharge or infection. ${ }^{2}$ Examination usually reveals a depression in the vermilion zone of the lip and opening into a blind sinus. Most cases can be treated by simple excision via an intraoral or extraoral approach.

\section{Learning points}

- Congenital pits of the lip are uncommon and may be associated with conditions such as Van der Woude syndrome.

- Isolated lip pits are extremely rare developmental defects. It is therefore important to investigate and exclude associated syndromes.

Contributors SH and KYW contributed equally. All the authors contributed significantly to the manuscript.

Competing interests None declared.

Patient consent Obtained.

Provenance and peer review Not commissioned; externally pee reviewed.

\section{REFERENCES}

1 Rizos M, Spyropoulos MN. Van der Woude syndrome: a review. Cardinal signs, epidemiology, associated features, differential diagnosis, expressivity, genetic counselling and treatment. Eur J Orthod 2004:26:17-24.

2 Fok D, Kua EHJ, Por YC. Congenital midline sinus of the upper lip. Singapore Med J 2015;56:e107-9.

Copyright 2016 BMJ Publishing Group. All rights reserved. For permission to reuse any of this content visit http://group.bmj.com/group/rights-licensing/permissions.

BMJ Case Report Fellows may re-use this article for personal use and teaching without any further permission.

Become a Fellow of BMJ Case Reports today and you can:

- Submit as many cases as you like

- Enjoy fast sympathetic peer review and rapid publication of accepted articles

- Access all the published articles

- Re-use any of the published material for personal use and teaching without further permission

For information on Institutional Fellowships contact consortiasales@bmjgroup.com

Visit casereports.bmj.com for more articles like this and to become a Fellow 